\title{
Assessment of Awareness and willingness of Eye Donation among Medical Students in Central India
}

\author{
Dr. Shakuntala Jitpure ${ }^{1}$ \\ (Associate Prof. Department Of Community Medicine, Chhattisgarh Institute of \\ Medical Sciences, Bilaspur. India)
}

\begin{abstract}
The Cornea is the clear tissue covering the front of the eye. It is a focusing element of the eye. The vision is dramatically reduced or lost if the cornea becomes cloudy. This loss of the vision is referred to as corneal blindness. As medical students are the future health care providers for the community. Our aim was to assess scientific knowledge of medical students whom can be expected to influence eye-donation rates In our study $1^{\text {st }}$ year and $2^{\text {nd }}$ year medical students of ,Chhattisgarh Institute of Medical Sciences Bilaspur (CIMS Bilaspur (CG)) were taken for this study. $1^{\text {st }}$ and $2^{\text {nd }}$ year medical students were chosen to eliminate bias of knowledge, as senior students may have better knowledge. A total of 270 students participated in the study. The questionnaire content question regarding their knowledge of proper time, place, for cornea donation parts of eye required for transplantation. Willingness to donate their eyes and reasons for not donating. Results of our study showed that only $65 \%$ of the students knew that cornea is the part of the eye required for transplantation, while $22 \%$ of students had the wrong idea that the whole eyeball is used for transplantation, whereas retina by $3 \%, 6 \%$ of students replied that whole eye was required and $4 \%$ of students did not knew which part was used in transplantation. Hence it can be concluded that level of knowledge of medical students are important determine in promoting eye donation as they are the future potential doctors.
\end{abstract}

Keywords: Medical Students, Eye Donation, Corneal Blindness, Pledging of eyes.

\section{Introduction}

Cornea is the clear tissue covering the front of the eye. The vision is dramatically reduced or lost if the cornea becomes cloudy. This loss of the vision is referred to as corneal blindness. As corneal diseases are significant causes of visual impairment and blindness in developing countries, cornea donation can be only used for keratroplasty. Till date though medical researchers and scientist are working on developing artificial cornea, but till hat time donating the eyes is the only source by which a person suffering from corneal blindness can be cured.

\section{Magnitude Of The Problem}

It is estimated that in India there are approximately 6.8 million people who have vision less than $6 / 60$ and at least one eye due to corneal diseases; among which, about a million have bilateral involvement. ${ }^{1,2}$ It is expected that the number of individuals with unilateral corneal blindness in India will increase to 10.6 million by 2020.(2) According to the National Programme for Control of Blindness (NPCB), there are currently 120,000 corneal blind persons in the country. According to this estimate there will be an addition of 25,00030,000 corneal blindness cases every year in the country.

There are many causes of corneal blindness some of them like injuries, malnutrition, infections chemical burns and congenital disorders. The burden of corneal disease in our country is reflected by the fact that $90 \%$ of the global cases of ocular trauma and corneal ulceration leading to corneal blindness occur in developing countries. ${ }^{4}$ The main hindrance regarding cornea donation are due to some common myths like, long time is required to remove the cornea from eye which may delay the funeral process ,the face get disfigured during removal of the eye which prevails in the society.

The eye donation of the deceased can be authorized by the next of kith \& kin even if the deceased did not pledge to donate his / her eyes before death. Age or systemic illness such as diabetes or hypertension, heart disease, kidney disease does not act as barriers for eye donations. Strategies if implemented successfully it will prevent $90 \%$ of the preventable blindness due to corneal disease by $2020 .^{5}$ Though many studies have shown that young college students are well aware of eye donation and most of them well interested to donate their eyes, but scientific knowledge regarding the place of eye donation, time duration for collection of cornea and person whom to contact and when to contact was still clearly not known. ${ }^{6,7,8,9}$. The study conducted in nursing college revealed that nursing students are also well aware of eye donation, ${ }^{10}$ 


\section{Aim \& Objectives}

Hence this study was undertaken with the objective to assess the awareness about proper knowledge about eye donation and also to study their willingness for eye donation among Ist and $2^{\text {nd }}$ year medical students.

\section{Methodology}

$1^{\text {st }}$ year and $2^{\text {nd }}$ year medical students of Chhattisgarh Institute of Medical Sciences Bilaspur (CIMS Bilaspur (CG)) were taken for this study. $1^{\text {st }}$ and $2^{\text {nd }}$ year medical students were chosen to eliminate bias of knowledge, as senior students may have better knowledge. A total of 270 students participated in the study. Out of 270 students 150 students were boys and 120 students were girls .The students were asked to fill a pretested questionnaire. The questionnaire content question regarding their knowledge of proper time, place, for cornea donation parts of eye required for transplantation.Willingness to donate their eyes and reasons for not donating. Responses of the students were evaluated to understand their knowledge regarding eye donation and willingness to pledge .Verbal consents were taken from the students before the beginning of the study.

\section{Observations and results}

Our study shows that in response to question regarding knowledge of eye bank as shown in table $1.28 \%$ of the students answered that they know there is a eye bank in their medical college, while $25 \%$ of them ever heard of any eye bank. When questioned about what is an eye bank $04 \%$ of the students answered it a place where eye are removed, $64 \%$ answered it is a place where eyes are collected and stored, $13 \%$ answered that it is a place where eyes are pledge. While $19 \%$ of students answered all above options.

Table 1. Students' response about awareness about eye banks

\begin{tabular}{|l|l|}
\hline Students' response about awareness about eye banks & Yes (\%) \\
\hline Dose your medical college have eye bank & 28 \\
\hline Do you know about any eye bank & 25 \\
\hline What is an eye bank & No of subjects (\%) \\
\hline It is a place where eyes are removed & 04 \\
\hline It is a place where eyes are collected and stored & 64 \\
\hline It is a place where eyes are pledge & 13 \\
\hline All of the above & 19 \\
\hline
\end{tabular}

Regarding their answers of which part of eye is used for transplantation as depicted in table $265 \%$ of students answered cornea is the part used for transplantation, while $22 \%$ answered whole eye is used, $03 \%$ retina is used for transplantation. Any part of the eye can be used was answered by $06 \%$ of the students and $04 \%$ of students said they don't know which part is used for transplantation.

Table2:- Response of students when question about which part of eye is used for transplantation

\begin{tabular}{|l|l|}
\hline Answer of students & No of student in (\%) \\
\hline Cornea is the part of the eye used for transplantation & 65 \\
\hline Whole eye ball is used for transplantation & 22 \\
\hline Retina is used for transplantation & 03 \\
\hline Any part of the eye & 06 \\
\hline Don't know & 04 \\
\hline
\end{tabular}

Table 3 shows response to questions about eye donation .15\% of the students answered it is necessary to transport the donor to the hospital after death for donating eyes, $15 \%$ of the students answered there may be disfigurement of the donor's face because of eye donation, while $22 \%$ of students said donation of eye may cause delay in funeral . Consent of relatives required for removal of eyes was answered by $32 \%$. Only $12 \%$ of the students have ever counseled any one for eye donation. 38\% of the students believed that donor or recipient family must have the knowledge who donated or received the cornea. While only $16 \%$ of the students have knowledge that transplantation of cornea also come under preview of human organ transplantation act 1994.Regarding awareness about conditions that render the corneas unfit was know by $23 \%$ of the students. Only $05 \%$ students know any person who has donated eyes and only $01 \%$ knows any person who has received eyes.08\% were aware about deficiency of eyes and $04 \%$ knew that in some religion religious authorities approval is required for donating of one's eyes. 
Table 3:- Students' response about eye donation

\begin{tabular}{|l|l|}
\hline Response of students & $\begin{array}{l}\text { No of students answered yes in } \\
(\%)\end{array}$ \\
\hline $\begin{array}{l}\text { Is it necessary to transport the donor to the hospital after } \\
\text { death for donating eyes }\end{array}$ & 30 \\
\hline Do eye donation cause disfigurement of the donor's face & 15 \\
\hline Do eye donation cause delay in funeral arrangements & 22 \\
\hline Is consent of relatives required for removal of eyes & 32 \\
\hline Have you counseled any one for eye donation & 12 \\
\hline $\begin{array}{l}\text { Is it necessary that donor or recipient family must be told } \\
\text { who donated or received the cornea }\end{array}$ & 38 \\
\hline $\begin{array}{l}\text { Do you have awareness about selling and buying of } \\
\text { donor eyes }\end{array}$ & 16 \\
\hline $\begin{array}{l}\text { Do you have knowledge about conditions that render the } \\
\text { corneas unfit }\end{array}$ & 23 \\
\hline Do you knows any person who has donated eyes & 05 \\
\hline Do you knows any person who has received eyes & 01 \\
\hline Are you have any awareness about deficiency of eyes & 08 \\
\hline $\begin{array}{l}\text { Are you aware that in some religion religious authorities } \\
\text { approval is necessary of donating one's eyes }\end{array}$ & 04 \\
\hline
\end{tabular}

While answering reason for not pledging their eyes, as shown from table 4. $82 \%$ response was that of lack of awareness, for $12 \%$ of the students it is an unacceptable idea of separating the eyes from the body. $03 \%$ response were that there are objection from family members. $02 \%$ response was that due to health problem they did not wish and $01 \%$ responded they do not wish to donate as they may be born blind in next birth.

Table 4:- Reasons for not pledging eyes for eye donation

\begin{tabular}{|l|l|}
\hline Reasons for not pledging eyes for eye donation & No of students in (\%) \\
\hline Lack of awareness & 82 \\
\hline Unacceptable idea of separating the eyes from the body & 12 \\
\hline Objection by family members & 03 \\
\hline Unsuitability to donate because of health problem & 02 \\
\hline Will be born blind in next birth & 01 \\
\hline
\end{tabular}

Table 5:- Response of students when asked about their willingness to pledge their eyes

\begin{tabular}{|l|l|}
\hline Willingness to donate eyes & Yes $(\%)$ \\
\hline Have you already pledge your eyes & 03 \\
\hline Are you willing to donate your eyes & 92 \\
\hline
\end{tabular}

As shown in table 5 regarding willingness of eye donation $92 \%$ of students were willing to donate their eyes but only $3 \%$ of the students had pledged their eyes

\section{Discussion}

The level of knowledge of medical students are important determine in promoting eye donation as they are the future potential doctors The major reason for not donating eyes was of course lack of proper knowledge and awareness. In our country with so many cases of corneal blindness there is a strong need for developing effective means of procuring cornea. Many potential donors may be missed if doctors themselves failed to approach their family members about the possibility of eye donation and if they lack sufficient knowledge about eye donation to answer questions or concerns of family members after death of the donors.

\section{Conclusion}

As corneal donation is the only source for curing corneal blindness, awareness in our society specially those who are involved in medical profession especially doctors must have proper scientific knowledge about eye donation, so they may spread the knowledge in the society which will ultimately create awareness regarding eye donation and will eliminate the myths prevailing in the society in context to eye donation . 


\section{References}

[1]. National Programme for Control of Blindness. Report of National Programme for Control of Blindness, India and World Health Organization. 1986-89

[2]. Dandona R, Dandona L. Corneal blindness in a southern Indian population: Need for health promotion strategies. Br J Ophthalmol. 2003;87:133-41.

[3]. National Programme for Control of Blindness. [Last accessed on 2016 October 30]. Available from: http://pbhealth.gov.in/pdf/Blindness.pdf

[4]. Whitcher JP, Srinivasan M, Upadhyay MP. Corneal blindness: A global perspective. Bull World Health Organ. 2001;79:214-21.

[5]. Dandona L, Dandona R, John RK. Estimation of blindness in India from 2000 through 2020: Implications for the blindness control policy. Natl Med J India. 2001;14:327-34

[6]. Sadana A, Sushma M, Lekha KC, Dudala SR, prabhu G, Reddy KK. Assessment of knowledge and attitude regarding eye donation among undergraduate medical students, Tirupati. Ijmps. 2014; 4(9): 16-24

[7]. Singh MM, Rahi M, Pagare D, Ingle G K. Medical students' perception on eye donation in Delhi. Indian J Ophthalmol 2007;55(1):49-52

[8]. Kumar S, Shukla US, Agarwal P. Awareness and Knowledge on Eye Donation Among Students at Bhopal. Natl J Community Med 2012; 3(4):685-9

[9]. Singh M, Bhardwaj A, Ahluwalia SK, Saini S, Qadri S. Eye donation: Perception and promoting factors among medical students' Indian J Of Community Health.2012;24(3):175-178

[10]. Gupta A, Jain S, Jain T, Gupta K. Awareness and Perception Regarding Eye Donation in Students of a Nursing College in Bangalore. Indian Journal of Community Med 2009;34:122-125 